\section{Identification of Red Maple Cultivars by Isozyme Analysis}

\author{
James J. Tobolski ${ }^{1}$ and Ricky D. Kemery ${ }^{2}$ \\ Department of Biological Sciences, Indiana University-Purdue \\ University, 2101 Coliseum Boulevard, East Fort Wayne, IN 46805-1499
}

Additional index words. Acer rubrum, starch gel electrophoresis, isoenzymes

\begin{abstract}
Dormant bud tissue from two or more trees representing 18 red maple (Acer rubrum L.) cultivars was subjected to isozyme analyses using starch-gel electrophoresis. Polymorphic enzymes resolved were alcohol dehydrogenase, peroxidase, phosphoglucase isomerase, glutamate oxaloacetate transaminase, leucine aminopeptidase, acid phosphatase, and malic dehydrogenase. An enzyme pattern or combination of patterns was useful in identifying individual cultivars, these included: 'Autumn Blaze', 'Autumn Flame', 'Bowhall', 'Celebration', 'Columnare', 'Curtis', 'Doric', 'Firedance', 'Gerling', Y.J. Drake', 'Morgan', 'Northwood', 'Scarlet Sentinel', 'Schlesingeri', and 'Tilford'. 'Armstrong', 'October Glory', and 'Red Sunset' could not be distinguished from each other on the basis of enzymes examined in this study.
\end{abstract}

Acer rubrum is a medium to large tree found in the eastern United States and Canada. Red maple's site adaptability and brilliant fall color make it one of the most valuable and widely planted species in metropolitan regions of the northeast United States (Gerhold et al., 1976). There are at least 35 cultivars of A. rubrum (Santamor and McCardle, 1982) and many nurseries have patented their most recent cultivars. However, authenticity of a particular cultivar could be difficult to prove. Morphological differences exist between cultivars, but these differences can be obscure and difficult to detect. Further, some differences, such as leaf morphology and fall color, depend on seasonal observation. As new cultivars are introduced, identification may become more difficult.

A reliable and objective method of identification might assist growers in resolving disputes regarding patent infringement or help to verify unlabeled or improperly labeled cultivars. Isozyme analysis has been shown to be an effective method for the identification of cultivars of several species (Estilai et al., 1990; Marquard et al., 1989; Tao and Sugiura, 1987). Isozyme analysis of Acer rubrum has been conducted as part of a taxonomic study of the genus Acer (Santamour, 1982) and also to determine differences between swamp and upland populations of native A. rubrum (Iglisch, 1981). The objective of this study was to determine if isozyme banding patterns could be used to distinguish red maple cultivars.

Tissue collection. Preliminary electrophofor publication 20 Sept. 1991. The cost of publishing this paper was defrayed in part by the payment of page charges. Under postal regulations, this paper therefore must be hereby marked $a d$ vertisement solely to indicate this fact.

${ }^{1}$ Associate Professor of Biology.

${ }^{2}$ Horticulture Student, Purdue Univ., West Lafayette, IN 47907.
Received for publication 7 Mar. 1991. Accepted liquid nitrogen and stored in small glass vials at $-70 \mathrm{C}$. Although fresh samples provided the strongest enzyme activity, well-macerated frozen tissue produced satisfactory gels.

At the time of analysis two or three buds were transferred to a small lucite tray with grinding wells and placed on ice. The tissue was hand ground with four to five drops of extraction buffer containing: $8 \%$ polyvinylpyrrolidone (7:1 of PVP 40,000; PVP 360,000), 0.33 м sucrose, 0.5 mm EDTA, $1 \mathrm{~mm}$ dithiothreitol, $1 \mathrm{~mm}$ ascorbic acid, $0.1 \%$ bovine serum albumin, 0.4 mM NAD, 0.3 mm NADP, and $0.2 \mathrm{~mm}$ pyridoxal 5-phosphate. The buffer was adjusted to $\mathrm{pH} 6.7$ with Tris and $0.66 \mathrm{ml} \beta$ - mercaptoethanol was added to $100 \mathrm{ml}$ buffer immediately before use (Cheliak and Pitel, 1984). Three gel and electrode buffer systems were used to resolve enzymes (Table 1). Systems A and B were those of Conkle et al. (1982), and the $\mathrm{H}$ system was that of Cheliak and Pitel(1984). Electrophoresis and staining procedures were similar to those described by Conkle et al. (1982). Sigma starch gels ranged in concentration from $10.5 \%$ to $11.5 \%$. All were run from $7.5 \mathrm{~cm}$ to $8.0 \mathrm{~cm}$ ( 4 to $5 \mathrm{~h}$ ) except for PGI, which was run to $12 \mathrm{~cm}$. Eight enzymes were resolved in dormant bud tissue for this study: alcohol dehydrogenase (ADH; EC 1.1.1.1), peroxidase (PER; EC 1.11.1.7), phosphoglucose isomerase (PGI; EC 5.3.1.9), glutamic oxaloacetic transaminase (GOT; EC 2.6.1.1), leucine aminopeptidase (LAP; EC 3.4.11.1), 6-phosphogluconic dehydrogenase (6 PGD; EC 1.1.1.44), acid phosphatase (ACP; EC 3.1.3.2), and malic dehydrogenase (MDH; EC 1.1.1.37). Tissue samples were electrophoresed three to eight times for each enzyme assayed. Shikimate dehydrogenase, fluorescent esterase, phosphoglucomutase, $\alpha-\beta$ esterase, catalase, and glutamate dehydrogenase were poorly resolved and are not presented.

Isozyme polymorphism was anticipated for red maple since it is genetically diverse and trees may be hexaploid, octoploid, or septaploid (Santamour, 1965). Further, it hybridizes with silver maple (A. saccharinum L.), and 'Autumn Blaze', 'Armstrong', 'Celebration', 'Morgan', and 'Scarlet Sentinel' are either hybrids or of putative hybrid origin (Dirr, 1990; Santamour and McArdle, 1982). Although this complexity precludes any genetic designation of loci and alleles,
Table 1. Gel and electrode buffers used to resolve enzymes.

\begin{tabular}{|c|c|c|c|c|}
\hline System & Enzymes & $\begin{array}{c}\text { Power } \\
(\mathrm{mA})\end{array}$ & Gel buffer & Electrode buffer \\
\hline A & $\begin{array}{l}\text { LAP, PER, } \\
\text { ADH, PGI }\end{array}$ & 50 & $\begin{array}{l}0.05 \mathrm{M} \text { Tris, } 0.0076 \mathrm{M} \text { citric } \\
\text { acid, } \mathrm{pH} 8.3,10 \% \text { electrode } \\
\text { buffer }\end{array}$ & $\begin{array}{l}0.029 \mathrm{M} \text { lithium hydroxide, } \\
0.19 \mathrm{M} \text { boric acid, } \mathrm{pH} 8.3\end{array}$ \\
\hline $\mathrm{B}$ & GOT, ACP & 40 & $\begin{array}{l}0.1 \mathrm{M} \text { Tris, } \mathrm{pH} 8.8 \text { with citric } \\
\text { acid }\end{array}$ & $\begin{array}{l}0.05 \mathrm{M} \mathrm{NaOH}, 0.3 \mathrm{M} \text { boric } \\
\text { acid, } \mathrm{pH} 8.0 \text { with } \mathrm{NaOH}\end{array}$ \\
\hline $\mathrm{H}$ & $\mathrm{MDH}, 6 \mathrm{PGD}$ & 40 & $\begin{array}{l}0.5 \mathrm{M} \text { histidine-HCL, } 1.40 \\
\text { mM EDTA, pH } 7.0 \text { with } \\
1.0 \mathrm{M} \text { 'l'ris (dilute } 4 \mathrm{H}_{2} \mathrm{O}: 1 \\
\text { stock) }\end{array}$ & $\begin{array}{l}0.125 \mathrm{M} \text { Tris, pH } 7.0 \text { with } 1.0 \\
\mathrm{M} \text { citric acid }\end{array}$ \\
\hline
\end{tabular}



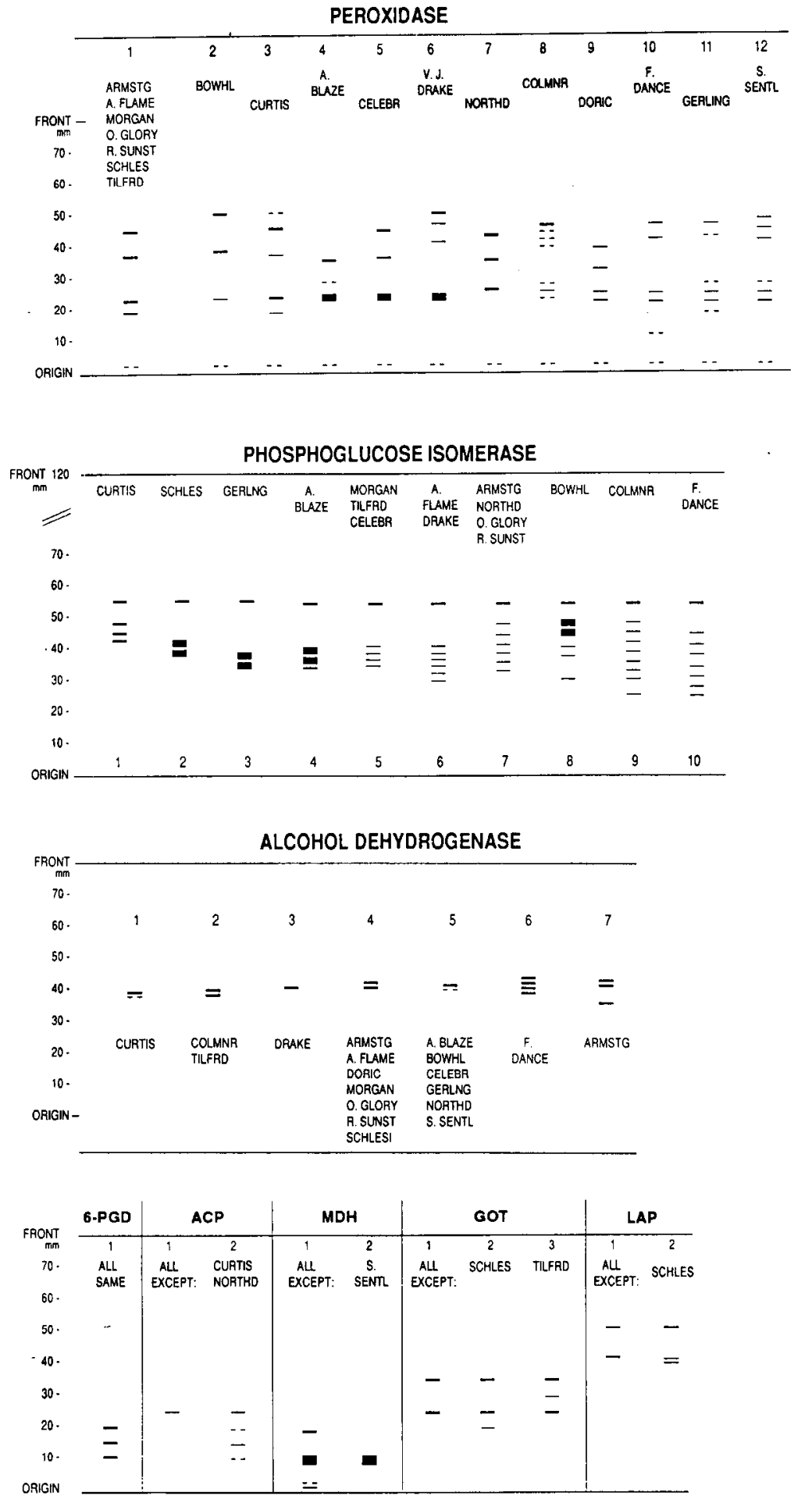

Fig. 1. Schematic illustrations of phenotypic banding patterns of eight enzyme systems in A. rubrum cultivars. Band widths correspond to the relative degree of staining intensity. Wide bands indicate intense activity, and dashed lines indicate weakly stained bands.

abundant polymorphism enhances the usefulness of isozyme markers for cultivar identification.

Phenotypic banding patterns of MDH, GOT, ACP, 6PGD, PER, and PGI were generally well resolved. ADH activity, however, was weak in dormant bud tissue; therefore, several additional gels were run to verify the small difference observed among phe- notypes. All of these enzymes were polymorphic except 6PGD, which displayed the same triple bands for all cultivars (Fig. 1).

Isozymes of PER, PGI (Fig. 2), and ADH were highly polymorphic, exhibiting 12,10 , and 7 banding patterns, respectively (Fig. 1). Together they can uniquely identify 14 cultivars. ACP, MDH, and LAP showed two distinct banding patterns each, and GOT dis- played three. Although these enzymes exhibit little polymorphism, they were still useful as gene markers since each has a rare pattern found for only one or two cultivars. Together these enzymes can be used to distinguish four cultivars.

Overall, 15 of 18 red maple cultivars could be identified by one or more phenotypic banding patterns. Thirteen of these selections exhibited a single unique pattern of one or more enzymes (Table 2). 'Celebration', 'Doric', and 'Northwood' could be identified by one or more phenotypic differences in PER, and a unique GOT pattern distinguished 'Tilford'.

Verification of identity was possible when two or more enzymes exhibited distinctive phenotypic patterns for a cultivar. 'Autumn Blaze', 'Bowhall', 'Columnare', and 'Gerling' showed distinctive patterns for PER and PGI. 'V.J. Drake' and 'Curtis' could be identified by specific bands of PER or ADH, and 'Scarlet Sentinel' could be identified by PER or MDH. Three unique patterns, GOT, LAP, and PGI identified 'Schlesingeri' and 'Fire Dance' could be distinguished by distinctive bands of PER, ADH, or PGI.

The identity of 'Morgan' and 'Autumn Flame' could only be resolved by the combined analysis of ADH and PGI. They both showed the ADH-4 band pattern, but 'Morgan' exhibited PGI-5 and 'Autumn Flame' PGI-6 (Fig. 1).

'Armstrong', 'October Glory', and 'Red Sunset' could not be clearly distinguished from one another in this study, despite obvious differences in their morphology and fall coloration. Seven 'Armstrong' trees produced the triple band ADH-7, but one sample from Secrest Arboretum produced ADH4, which was common to six other cultivars (Fig. 1). To resolve the identity of these selections and perhaps others, analyses of additional enzymes and/or the use of different tissues may prove beneficial.

To a large degree, the morphological and physiological diversity of $A$. rubrum is reflected by its abundant enzyme polymorphism. Thus, isozyme analysis appears to be a useful tool to establish cultivar identity.

\section{Literature Cited}

Cheliak, W.M. and J.A. Pitel. 1984. Genetic control of allozyme variants in mature tissues of white spruce trees. J. Hered. 75:34-40.

Conkle, M.T., R.D. Hodgskiss, L.B. Nunnally, and S.C. Hunter. 1982. Starch gel electrophoresis of conifer seeds: a laboratory manual. U.S. Dept. Agr. Gen. Technol. Rpt. PSW-64.

Dirr, M.A. 1990. Manual of woody landscape plants. 4th ed. Stipes Publ. Co., Champaign, Ill.

Estilai, A., A. Hashemi, and J.G. Waines. 1990. Isozyme markers for cultivar identification in guayule. HortScience 25:346-348.

Gerhold, H.D., D.B. Zeaser, K.C. Steiner, and A.M. Townsend. 1976. Genetic variation in red maple rootstocks. Proc. N.E. Tree Imp. Conf. Rutgers Univ., New Brunswick, N.J. 23:8693. 
Table 2. Phenotypic banding patterns of red maple cultivars. The number of the banding pattern refers to the isozyme patterns in Fig. 1.

\begin{tabular}{|c|c|c|c|c|c|c|c|c|}
\hline Cultivar & $\begin{array}{c}\text { No. } \\
\text { sampled }\end{array}$ & $\mathrm{ACP}$ & $\mathrm{ADH}$ & GOT & LAP & $\mathrm{MDH}$ & PER & PGI \\
\hline Autumn Blaze & 2 & 1 & 5 & 1 & 1 & 1 & 4 & 4 \\
\hline Autumn Flame & 4 & -1 & 4 & 1 & 1 & 1 & 1 & 6 \\
\hline Armstrong & 8 & 1 & $4^{z} / 7$ & 1 & 1 & 1 & 1 & 7 \\
\hline Bowhall & 6 & 1 & 5 & 1 & 1 & 1 & 2 & 8 \\
\hline Celebration & 1 & 1 & 5 & 1 & 1 & 1 & 5 & 5 \\
\hline Columnare & 3 & 1 & 2 & 1 & 1 & 1 & 8 & 9 \\
\hline Curtis & 1 & 2 & 1 & 1 & 1 & 1 & 3 & 1 \\
\hline Doric & 2 & 1 & 4 & 1 & 1 & 1 & 9 & 1 \\
\hline Firedance & 4 & 1 & 6 & 1 & 1 & 1 & 10 & 10 \\
\hline Gerling & 4 & 1 & 5 & 1 & 1 & 1 & 11 & 3 \\
\hline V.J. Drake & 4 & 1 & 3 & 1 & 1 & 1 & 6 & 6 \\
\hline Morgan & 2 & 1 & 4 & 1 & 1 & 1 & 1 & 5 \\
\hline Northwood & 4 & 2 & 5 & 1 & 1 & 1 & 7 & 7 \\
\hline October Glory & 9 & 1 & 4 & 1 & 1 & 1 & 1 & 7 \\
\hline Red Sunset & 8 & 1 & 4 & 1 & 1 & 1 & 1 & 7 \\
\hline Scarlet Sentinel & 6 & 1 & 5 & 1 & 1 & 2 & 12 & -- \\
\hline Schlesingeri & 4 & 1 & 4 & 2 & 2 & 1 & 1 & 2 \\
\hline Tilford & 3 & 1 & 2 & 3 & 1 & 1 & 1 & 5 \\
\hline
\end{tabular}

${ }^{2}$ Pattern 4 observed in one individual.

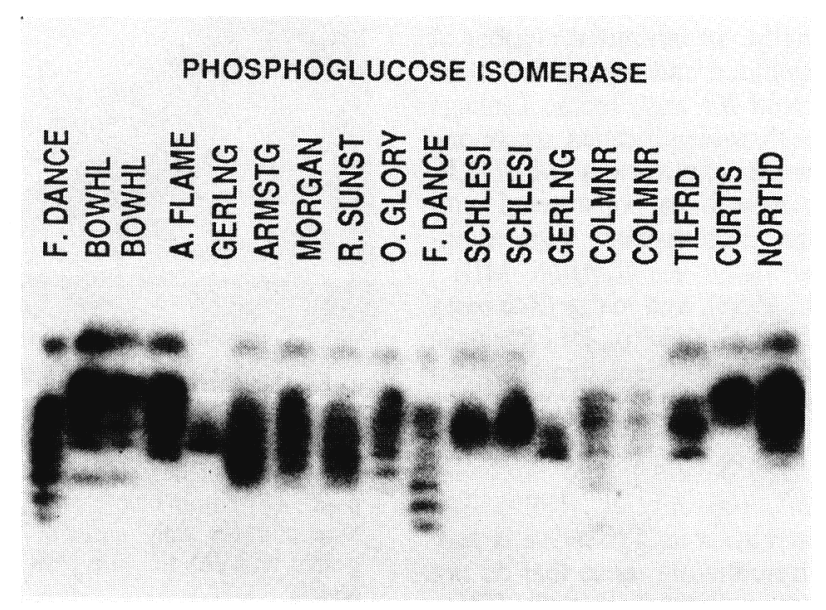

Fig. 2. Anodal gel of PGI allozyme phenotypes representing a selection of A. rubrum cultivars.
Iglich, E.M. 1981. The demographic-genetics of red maple (Acer rubrum L.) PhD Diss., Univ. of Georgia, Athens.

Marquard, R.D., J.L. Tipton, and R.G. Skorpenske. 1989. Isozyme variation among desert willow cultivars. HortScience 24:350-351.

Santamour, F.S., Jr. 1965. cytological studies in red and silver maples and their hybrids. Bul. Torrey Bot. club 92127-134.

Santamour, F.S., Jr. 1982. Cambial peroxidase isoenzymes in relation to systematics of Acer. Bul. Torrey Bot. Club. 109:152-161.

Santamour, F.S., Jr., and A.J. McArdle. 1982. Checklist of cultivated maples. I. Acer rubrum L. J. Arboriculture 8:110-112.

Tao, R. and A. Sugiura. 1987. Cultivar identification of Japanese persimmon by leaf isozymes. HortScience 22:932-935. 